Article

\title{
Facile Route for Bio-Phenol Siloxane Synthesis via Heterogeneous Catalytic Method and its Autonomic Antibacterial Property
}

\author{
Xiaoyan Pang ${ }^{1}$, Xin Ge ${ }^{1}$, Jianye Ji ${ }^{1}$, Weijie Liang ${ }^{2}{ }^{\oplus}$, Xunjun Chen ${ }^{1}{ }^{\circledR}$ and Jianfang Ge ${ }^{1, *}$ \\ 1 College of Chemistry and Chemical Engineering, Zhongkai University of Agriculture and Engineering, \\ Guangzhou 510225, China; shelly_pxy@163.com (X.P.); gexin@zhku.edu.cn (X.G.); jjyjasonky@163.com (J.J.); \\ cxj.qiao@163.com (X.C.). \\ 2 School of Materials Science and Engineering, Northwestern Polytechnical University, Xi'an 710072, China; \\ leungvijer@163.com \\ * Correspondence: ge650704@163.com; Tel.: +86-159-196-571-48
}

Received: 12 September 2018; Accepted: 11 October 2018; Published: 16 October 2018

\begin{abstract}
Eugenol, used as bio-phenol, was designed to replace the hydrogen atom of hydrogenterminated siloxane by hydrosilylation reaction under the presence of alumina-supported platinum catalyst $\left(\mathrm{Pt}-\mathrm{Al}_{2} \mathrm{O}_{3}\right)$, silica-supported platinum catalyst $\left(\mathrm{Pt}-\mathrm{SiO}_{2}\right)$ and carbon nanotube-supported platinum catalyst (Pt-CNT), respectively. The catalytic activities of these three platinum catalysts were measured by nuclear magnetic resonance hydrogen spectrometer $\left({ }^{1} \mathrm{H}\right.$ NMR). The properties of bio-phenol siloxane were characterized by Fourier transform infrared spectrometer (FT-IR), UV-visible spectrophotometer (UV) and thermogravimeter (TGA), and its antibacterial property against Escherichia coli was also studied. The results showed that the catalytic activity of the catalyst Pt-CNT was preferable. When the catalyst concentration was $100 \mathrm{ppm}$, the reaction temperature was $80{ }^{\circ} \mathrm{C}$ and reaction time was $6 \mathrm{~h}$, the reactant conversion rate reached $97 \%$. After modification with bio-phenol, the thermal stability of the obtained bio-phenol siloxane was improved. For bio-phenol siloxane, when the ratio of weight loss reached $98 \%$, the pyrolysis temperature was raised to $663{ }^{\circ} \mathrm{C}$ which was $60{ }^{\circ} \mathrm{C}$ higher than hydrogenterminated siloxane. Meanwhile, its autonomic antibacterial property against Escherichia coli was improved significantly.
\end{abstract}

Keywords: bio-phenol siloxane; synthesis; supported platinum catalyst; autonomic antibacterial

\section{Introduction}

A bio-phenol is a phenol that derives from natural products, for example, vegetablse, tea-leaves, and flowers. Eugenol (4-allyl-2-methoxyphenol) is one kind of bio-phenol, which is a primary constituent of plant essential oil such as clove oil, laurel oil and camphor oil and characterized by the presence of functional groups such as hydroxy group, methoxy group and allyl group. Because of this unique structure, eugenol has biological and chemical characteristics, for example, antibacterial activity, antioxidant activity thermal stability and chemical reactivity [1-4]. Eugenol is particularly widely used in the food, cosmetic, and pharmaceutical industries [5,6]. Meanwhile, eugenol was used in compound modification [7,8]. Dai [9] used eugenol in the synthesis of eugenol-based organic coatings and the results indicated that the coating showed outstanding thermal stability and excellent adhesion. Miao [10] used eugenol in the synthesis of bio-based epoxy resin and the results showed the product had outstanding comprehensive performances and high renewable carbon content. Mangeon [11] used eugenol in the synthesis of semi-interpenetrating polymer networks and used it as plasticizer of poly-(3-hydroxyalkanoate), and the results showed the compound exhibited excellent deformability. Silva [12] studied eugenol derivatives which had excellent antibacterial and antioxidant activities. 
Eugenol could replace the hydrogen atom of hydrogenterminated siloxane by hydrosilylation reaction between allyl group and silicon hydrogen group under the presence of platinum catalyst. The platinum catalysts were commonly homogeneous catalysts such as Speier's catalyst and Karsted's catalyst [13-15]. The homogeneous catalyst was corrosive to reactors, difficult to remove from the system and had poor selection of reaction, and thus limited the application in specific fields [16,17]. Recently, the supported platinum catalysts are attracting researchers' interest because of excellent catalytic selectivity and their simplicity of removal [18-22]. It is notable that supported catalysts have different catalytic activities in the reaction because of the different properties of supported material.

In this paper, eugenol, used as a bio-phenol, was designed to replace the hydrogen atom of hydrogenterminated siloxane by hydrosilylation reaction under the presence of

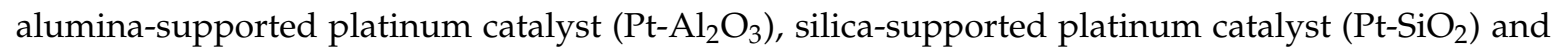
carbon nanotube-supported platinum catalyst (Pt-CNT). The catalytic activities of these three catalysts were measured by nuclear magnetic resonance hydrogen $\left({ }^{1} \mathrm{H} N \mathrm{NR}\right)$ spectrometer, thereby determining the preferable process conditions. The product, bio-phenol siloxane, was characterized by Fourier transform infrared spectrometer (FT-IR), ultravioler-visible (UV) spectrophotometer and thermogravimeter, and its antibacterial activity against Escherichia coli was studied.

\section{Materials and Methods}

\subsection{Materials}

Eugenol of $98 \%$ purity was purchased from Guangdong Tongcai New Material Corporation (Guangzhou, China). Octamethylcyclotetrasiloxane $\left(\mathrm{D}_{4}\right)$ and 1,1,3,3-tetramethyldisiloxane (HMMH) were obtained from Shenzhen Ji-Peng Silicon Fluoride Materials Corporation (Shenzhen, China). Macroporous cationic resin was gained from Jiangyin Nanda Synthesis Chemical Corporation (Jiangyin, China). Catalyst $\mathrm{Pt}-\mathrm{Al}_{2} \mathrm{O}_{3}$ with $3 \% \mathrm{Pt}$ and catalyst $\mathrm{Pt}-\mathrm{SiO}_{2}$ with $3 \% \mathrm{Pt}$ were obtained from Hubei Xinrunde Chemical Corporation (Wuhan, China). Chloroplatinic acid was purchased from Shanghai SSS Reagent Corporation (Shanghai, China). CNT was obtained from Qinhuangdao ENO High-Tech Material Development Corporation (Qinhuangdao, China). Agar nutrient solution and Escherichia coli solution were prepared from biochemical laboratory in Zhongkai University of Agriculture and Engineering. Ethanol (AR) was supplied by Tianjin Kemiou Chemical Corporation (Tianjin, China).

\subsection{Synthesis of Bio-Phenol Siloxane}

CNT $(2.0 \mathrm{~g})$ and ethanol $(35 \mathrm{~mL})$ were added into a $100 \mathrm{~mL}$ three-necked flask equipped with a magnetic stirrer, a nitrogen inlet and a condenser. After venting nitrogen for $30 \mathrm{~min}, 15 \mathrm{~mL}$ chloroplatinic acid-ethanol solution was added. Then the system was heated to $75{ }^{\circ} \mathrm{C}$ for $10 \mathrm{~h}$. After washed and dried, the catalyst Pt-CNT was prepared successfully and the concentration of $\mathrm{Pt}$ was $3 \%$.

$\mathrm{D}_{4}(122.1 \mathrm{~g}, 0.4125 \mathrm{~mol}), \mathrm{HMMH}(4.02 \mathrm{~g}, 0.03 \mathrm{~mol})$ and macroporous cationic resin $(3.78 \mathrm{~g}$, $3 \%$ ) were added into a $250 \mathrm{ml}$ three-necked flask equipped with a magnetic stirrer, a thermometer and a reflux condenser. The system was heated to $80{ }^{\circ} \mathrm{C}$ for $4 \mathrm{~h}$ then purified at $150{ }^{\circ} \mathrm{C}$ for $4 \mathrm{~h}$. The hydrogenterminated siloxane was synthesized.

Hydrogenterminated siloxane $(80 \mathrm{~g}, 0.02 \mathrm{~mol})$ and eugenol $(6.56 \mathrm{~g}, 0.04 \mathrm{~mol})$ were placed in a 150-mL three-necked flask equipped with a magnetic stirrer, a nitrogen inlet, and a condenser. After venting nitrogen for $30 \mathrm{~min}$, the appropriate amount of catalyst was added into the three-necked flask, and then the reaction system was heated to set temperature under nitrogen atmosphere for $6 \mathrm{~h}$. Then, after centrifugation for $1 \mathrm{~h}$, viscous oil was obtained. The viscous oil is bio-phenol siloxane. Figure 1 showed the scheme of synthesis of bio-phenol siloxane. 
<smiles>CC(C)(C)C</smiles>

D4<smiles>C[SiH](C)O[Si](C)(C)C</smiles>

HMMH

\section{catalyst}<smiles>C=CCc1ccc(O)c(OC)c1</smiles>

Eugenol

\section{Hydrogenterminated siloxane}<smiles>COc1cc(CCCCC(C)(C)[Si](C)(C)OC(C)(C)[Si](C)(C)CCCCc2ccc(O)c(OC)c2)ccc1O</smiles>

\section{Bio-phenol siloxane}

Figure 1. Scheme of synthesis of bio-phenol terminated organosiloxane.

\subsection{Nuclear Magnetic Resonance Hydrogen $\left({ }^{1} H\right.$ NMR) Spectrometer Analysis}

The ${ }^{1} \mathrm{H}$ NMR spectrum were recorded on a Bruker Avance IIIHD 500 spectrometer (Bruker Corporation, Karlsruhe, Germany) using $\mathrm{CDCl}_{3}$ as a solvent. The chemical shifts relative to tetramethylsilane, which is used as an internal reference. The yield was calculated by the integration intensity of absorption peak of $\mathrm{C}=\mathrm{CH}_{2}$ or $\mathrm{Si}-\mathrm{H}$.

\subsection{Fourier Transform Infrared (FT-IR) Analysis}

FT-IR spectrum of hydrogenterminated siloxane and bio-phenol siloxane were conducted on a Perkin Elmer FT-IR spectrum 100 (Perkin-Elmer Corporation, Fremont, CA, USA) at room temperature. Before scanning, the samples were dried in the drying cabinet at $80^{\circ} \mathrm{C}$ for $4 \mathrm{~h}$ to remove moisture. The samples were scanned within the range from 400 to $4000 \mathrm{~cm}^{-1}$.

\subsection{Ultraviolet-Visible (UV) Analysis}

UV-vis spectra were recorded on a UV-1800 UV-vis spectrophotometer (Perkin-Elmer Corporation, Fremont, CA, USA) within the range from 200 to $400 \mathrm{~nm}$. The samples were dissolved in the ethanol.

\subsection{Thermal Analysis}

Thermogravimetric analyses were carried out using a Mettler Toledo TG/DTA thermal analyzer (Mettler-Toledo AG Corporation, Columbus, OH, USA) to measure the temperature of siloxane from the beginning of weight loss to $100 \%$ weight loss. The experiments were performed in the range of $40-900{ }^{\circ} \mathrm{C}$ at a heating rate of $10^{\circ} \mathrm{C} / \mathrm{min}$ under nitrogen atmosphere.

\subsection{Antimicrobial Activity}

Antimicrobial activity was measured according to a spread plate method using Escherichia coli [23]. The amounts of Escherichia coli used for the assay were optimized to better visualize the antimicrobial effect caused by eugenol, hydrogenterminated siloxane and bio-phenol siloxane. The agar plates with Escherichia coli were placed into the biochemical incubator at $35^{\circ} \mathrm{C}$ for $22 \mathrm{~h}$. Optical images of incubated plates were taken with a mobile phone. The amounts of Escherichia coli bacterial colonies were observed by manual counting. 


\section{Results and Discussions}

\subsection{Analysis of Catalytic Activity}

\subsubsection{Catalytic Activity of $\mathrm{Pt}-\mathrm{Al}_{2} \mathrm{O}_{3}$}

Table 1 shows the effect of reaction temperature on activity of the catalyst $\mathrm{Pt}-\mathrm{Al}_{2} \mathrm{O}_{3}$ when the amount of catalyst was $100 \mathrm{ppm}$. The reaction time was set to $6 \mathrm{~h}$ in all experiments. As shown in the Table 1, when the reaction temperature was $80^{\circ} \mathrm{C}$, the product was stratified and this explains the existence of unreacted eugenol which was yellowish. By raising the reaction temperature, the degree of reaction improved, and the yellowing degree of product also enhanced, which was detrimental. When the temperature was increased to $160{ }^{\circ} \mathrm{C}$, the product turned into yellow turbid liquid. As the result shows, the preferable temperature for catalyst $\mathrm{Pt}-\mathrm{Al}_{2} \mathrm{O}_{3}$ was $100{ }^{\circ} \mathrm{C}$ and the sample $\mathrm{A}-2$ was preferable. Figure 2a shows the ${ }^{1} \mathrm{H}$ NMR spectrum of sample A-2. As the Figure 2a shown, the signals at 5.9, 5.1, and $4.7 \mathrm{ppm}$ were corresponding to $\mathrm{C}=\mathrm{CH}-,-\mathrm{C}=\mathrm{CH}_{2}$ and $\mathrm{Si}-\mathrm{H}$ group. The ratio of the integration intensity of these three signals is 1:2:1, which matched well with the value calculated according to the structure. This indicated that the reaction system still had unreacted $\mathrm{C}=\mathrm{CH}-,-\mathrm{C}=\mathrm{CH}$ and $\mathrm{Si}-\mathrm{H}$ group and the yield was $36 \%$ by calculating the integration intensity of signal of the $\mathrm{Si}-\mathrm{H}$ group. Table 2 shows the effect of catalyst concentration on the activity of catalyst $\mathrm{Pt}-\mathrm{Al}_{2} \mathrm{O}_{3}$ when the reaction temperature was $100^{\circ} \mathrm{C}$. As Table 2 shown, when the catalyst concentration was increased to $500 \mathrm{ppm}$, the product was still turbid liquid (Sample A-10). Figure $2 \mathrm{~b}$ shows the ${ }^{1} \mathrm{H}$ NMR spectrum of sample A-10 and we can see the signals of unreacted $\mathrm{C}=\mathrm{CH}-,-\mathrm{C}=\mathrm{CH}_{2}$ and $\mathrm{Si}-\mathrm{H}$ group. The yield was 76\%. As known, the turbidity of product demonstrated the reaction degree of system. When the yield was as high as possible, the product was transparent. It was revealed that the catalyst $\mathrm{Pt}-\mathrm{Al}_{2} \mathrm{O}_{3}$ had a low catalytic activity in this hydrosilylation reaction between eugenol and hydrogenterminated siloxane.

Table 1. Effect of reaction temperature on activity of catalyst.

\begin{tabular}{ccccc}
\hline Samples & Catalys $(\mathbf{p p m})$ & Temperature $\left({ }^{\circ} \mathbf{C}\right)$ & Appearance & Yield (\%) \\
\hline A-1 & 100 & 80 & Stratified, the bottom layer was unreactive eugenol & - \\
A-2 & 100 & 100 & Not stratified, as colorless turbid liquid & 36 \\
A-3 & 100 & 120 & Not stratified, as pale yellowish turbid liquid & - \\
A-4 & 100 & 140 & Not stratified, as yellowish turbid liquid & - \\
A-5 & 100 & 160 & Not stratified, as yellow turbid liquid & - \\
\hline
\end{tabular}
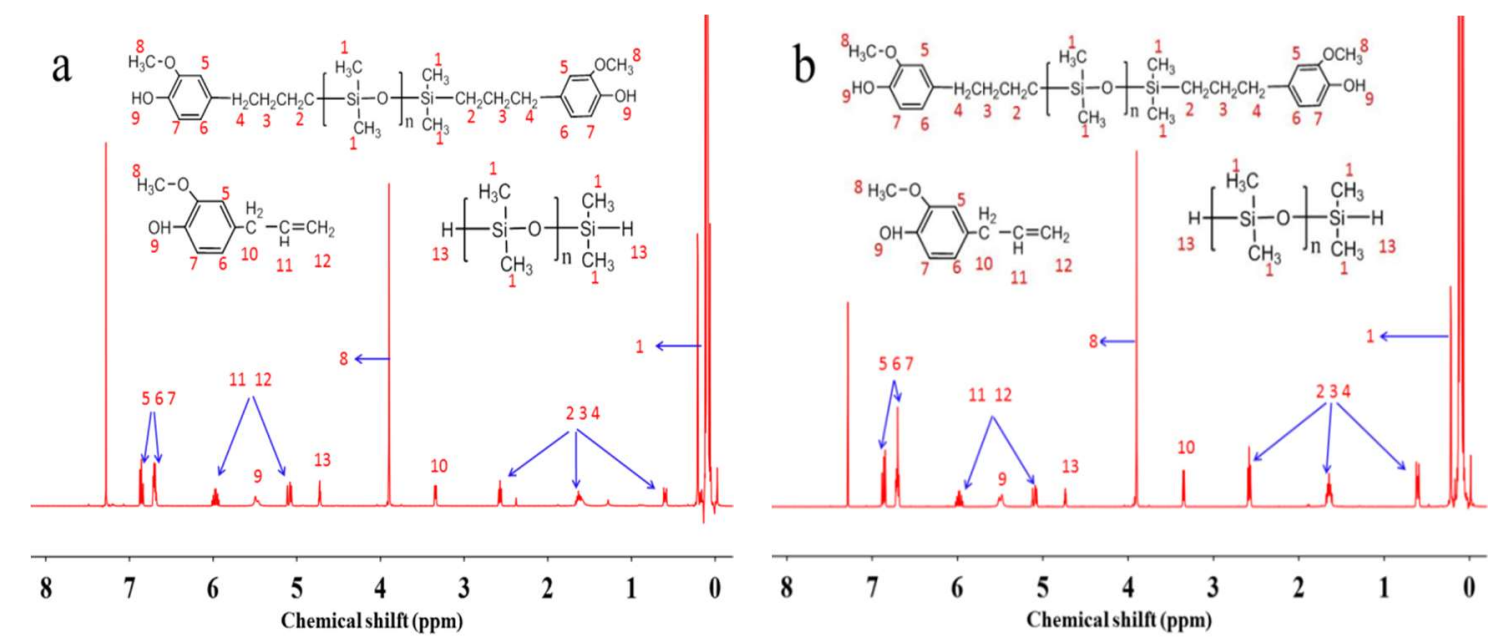

Figure 2. Nuclear magnetic resonance hydrogen $\left({ }^{1} \mathrm{H}\right.$ NMR) spectrum of sample A-2 (a) and A-10 (b). 
Table 2. Effect of catalyst concentration on activity of catalyst.

\begin{tabular}{ccccc}
\hline Samples & Catalyst $(\mathbf{p p m})$ & Temperature $\left({ }^{\circ} \mathbf{C}\right)$ & Appearance & Yield (\%) \\
\hline A-6 & 50 & 100 & Stratified, the bottom layer was unreactive eugenol & - \\
A-7 & 100 & 100 & Not stratified, as colorless turbid liquid & - \\
A-8 & 100 & 100 & Not stratified, as colorless turbid liquid & - \\
A-9 & 200 & 100 & Not stratified, as colorless turbid liquid & - \\
A-10 & 500 & 100 & Not stratified, as colorless turbid liquid & 76 \\
\hline
\end{tabular}

\subsubsection{Catalytic Activity of $\mathrm{Pt}_{-} \mathrm{SiO}_{2}$}

Table 3 shows the effect of reaction temperature on activity of catalyst $\mathrm{Pt}_{-} \mathrm{SiO}_{2}$ when the amount of catalyst was $100 \mathrm{ppm}$. We knew that as the temperature exceeded $100{ }^{\circ} \mathrm{C}$, the product would be turn into yellow, so the temperature was setting at range of $60-100^{\circ} \mathrm{C}$. As Table 3 shown, when temperature was $60^{\circ} \mathrm{C}$, the solution was stratified. When the temperature increased to $100{ }^{\circ} \mathrm{C}$, the solution had turned into yellowish (Sample B-3). Figure 3a is the ${ }^{1} \mathrm{H}$ NMR spectrum of sample B-3 and its yield was $66 \%$ by calculating the integration intensity of signal of $\mathrm{Si}-\mathrm{H}$ group. Table 4 shows the effect of catalyst concentration on activity of catalyst $\mathrm{Pt}_{-} \mathrm{SiO}_{2}$ when the reaction temperature was $80{ }^{\circ} \mathrm{C}$. As Table 2 shown, when the catalyst concentration was increased to $200 \mathrm{ppm}$, the product was colorless and slight transparent liquid (Sample B-7). Figure $3 \mathrm{~b}$ is the ${ }^{1} \mathrm{H}$ NMR spectrum of sample B-7 and its yield was $80 \%$ by calculating the integration intensity of signal of $\mathrm{Si}-\mathrm{H}$ group. It was revealed that catalyst $\mathrm{Pt}-\mathrm{SiO}_{2}$ had a higher catalytic activity than catalyst $\mathrm{Pt}_{-} \mathrm{Al}_{2} \mathrm{O}_{3}$ in this hydrosilylation reaction. But catalytic activity of catalyst $\mathrm{Pt}-\mathrm{SiO}_{2}$ was not high enough to meet production requirements.

Table 3. Effect of reaction temperature on activity of catalyst.

\begin{tabular}{ccccc}
\hline Samples & Catalyst (ppm) & $\begin{array}{c}\text { Temperature } \\
\left({ }^{\circ} \mathbf{C}\right)\end{array}$ & Appearance & Yield (\%) \\
\hline B-1 & 100 & 60 & Stratified, the bottom layer was unreactive eugenol & - \\
B-2 & 100 & 80 & Not stratified, as colorless turbid liquid & - \\
B-3 & 100 & 100 & Not stratified, as yellowish, little transparent liquid & 66 \\
\hline
\end{tabular}

Table 4. Effect of catalyst concentration on activity of catalyst.

\begin{tabular}{ccccc}
\hline Samples & $\begin{array}{c}\text { Catalyst } \\
(\mathbf{p p m})\end{array}$ & Temperature $\left({ }^{\circ} \mathbf{C}\right)$ & Appearance & Yield (\%) \\
\hline B-4 & 10 & 80 & Not stratified, as colorless turbid liquid & - \\
B-5 & 50 & 80 & Not stratified, as colorless turbid liquid & - \\
B-6 & 100 & 80 & Not stratified, as colorless turbid liquid & - \\
B-7 & 200 & 80 & Not stratified, as colorless, slight transparent liquid & 80 \\
\hline
\end{tabular}
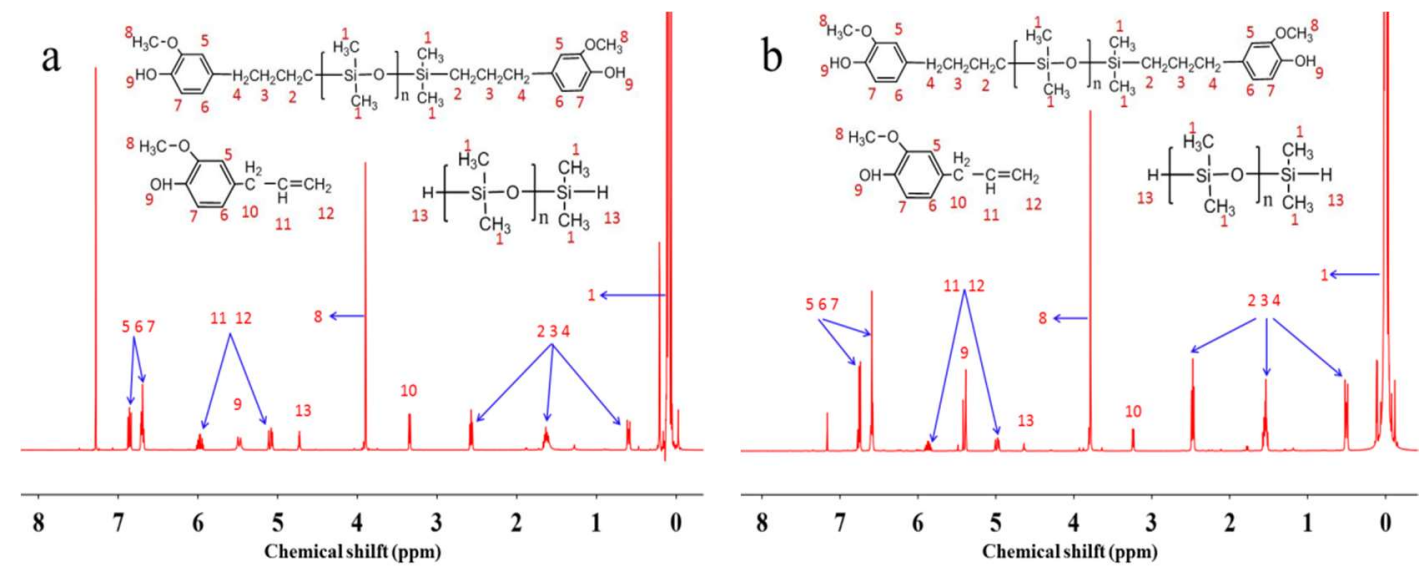

Figure 3. ${ }^{1} \mathrm{H}$ NMR spectrum of sample B-3 (a) and B-7 (b). 


\subsubsection{Catalytic Activity of Pt-CNT}

Table 5 shows the effect of reaction temperature on activity of catalyst Pt-CNT when the amount of catalyst was $100 \mathrm{ppm}$ and the temperature was set at a range of $60-100{ }^{\circ} \mathrm{C}$. As Table 5 shows, when temperature was $60^{\circ} \mathrm{C}$, the solution was colorless and a slightly transparent liquid. When the temperature increased to $80^{\circ} \mathrm{C}$, the solution was a colorless transparent liquid (Sample C-2). Figure 4 is the ${ }^{1} \mathrm{H}$ NMR spectrum of sample C-2. As Figure 4 shown, the signals at 5.9, 5.1, and $4.7 \mathrm{ppm}$ had nearly disappeared which were corresponding to $\mathrm{C}=\mathrm{CH}-,-\mathrm{C}=\mathrm{CH}_{2}$ and $\mathrm{Si}-\mathrm{H}$ group. The yield was $97 \%$ by calculating the integration intensity of signal of the $\mathrm{Si}-\mathrm{H}$ group. Table 6 shows the effect of catalyst concentration on activity of catalyst Pt-CNT when the reaction temperature was $80^{\circ} \mathrm{C}$. By decreasing the catalyst concentration, the reaction degree declined. Combined with the analysis above, it was shown that the catalytic activity of catalyst Pt-CNT was preferable compared with catalyst $\mathrm{Pt}-\mathrm{Al}_{2} \mathrm{O}_{3}$ and catalyst $\mathrm{Pt}-\mathrm{SiO}_{2}$ in this hydrosilylation reaction between eugenol and hydrogenterminated siloxane. This was because the CNT had a larger specific surface area and thus had a better contact with the reactants. Meanwhile, when catalyst Pt-CNT was used 4 times after recyling, it also had a high catalytic activity and the yield was still more than $90 \%$.

Table 5. Effect of reaction temperature on activity of catalyst.

\begin{tabular}{ccccc}
\hline Samples & Catalyst $(\mathbf{p p m})$ & Temperature $\left({ }^{\circ} \mathrm{C}\right)$ & Appearance & Yield $(\%)$ \\
\hline C-1 & 100 & 60 & Not stratified, as colorless and slight transparent liquid \\
C-2 & 100 & 80 & Not stratified, as colorless transparent liquid & - \\
C-3 & 100 & 100 & Not stratified, as yellowish and slight transparent liquid & - \\
\hline
\end{tabular}

Table 6. Effect of catalyst concentration on activity of catalyst.

\begin{tabular}{ccccc}
\hline Samples & Catalyst $(\mathbf{p p m})$ & Temperature $\left({ }^{\circ} \mathbf{C}\right)$ & Appearance & Yield $(\%)$ \\
\hline C-4 & 30 & 80 & Not stratified, as colorless and slight transparent liquid & - \\
C-5 & 50 & 80 & Not stratified, as colorless and slight transparent liquid & - \\
C-6 & 100 & 80 & Not stratified, as colorless transparent liquid & 97 \\
\hline
\end{tabular}

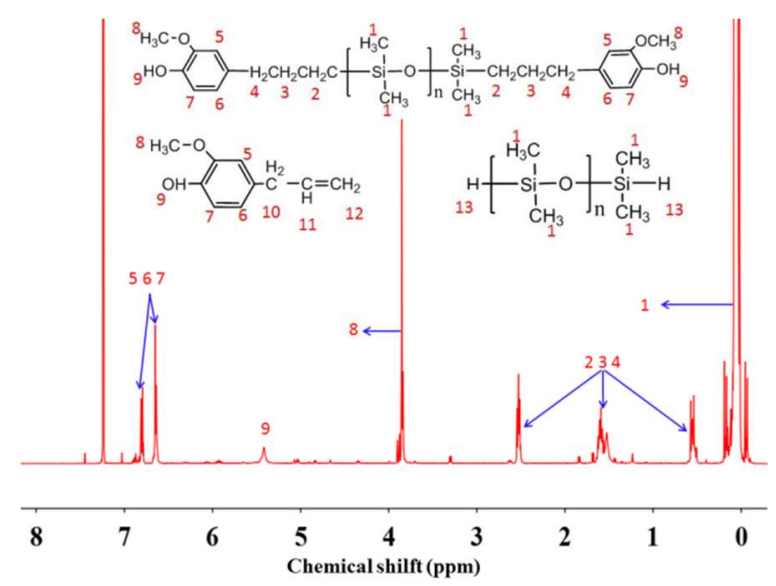

Figure 4. ${ }^{1} \mathrm{H}$ NMR spectrum of sample C-2.

\subsection{FT-IR Analysis}

For a better understanding of the difference between hydrogenterminated siloxane and bio-phenol terminated siloxane (Sample C-2), Fourier transform infrared spectroscopy was employed to identify their functional groups. Figure 5 shows the FTIR spectrum of hydrogenterminated siloxane (a) and bio-phenol terminated siloxane (b). In both curves, an absorption peak appeared at 2900, 1300 and $1050 \mathrm{~cm}^{-1}$ corresponding to $\mathrm{C}-\mathrm{H}$ stretching vibration, $\mathrm{C}-\mathrm{H}$ in-plane bending vibration and $\mathrm{Si}-\mathrm{O}-\mathrm{Si}$ stretching vibration in turn. In curve a, a characteristic peak appeared at $2200 \mathrm{~cm}^{-1}$ was corresponding to $\mathrm{Si}-\mathrm{H}$ stretching vibration in the molecular structure of hydrogenterminated siloxane. In curve $b$, 
the absorption peak of Si-H had disappeared, and two new characteristic peaks appeared at 3500 and $1500 \mathrm{~cm}^{-1}$ corresponding to $\mathrm{O}-\mathrm{H}$ and benzene stretching vibration, which were derived from eugenol. It was indicated that the eugenol was connected to hydrogenterminated siloxane and bio-phenol terminated siloxane was synthesized successfully.

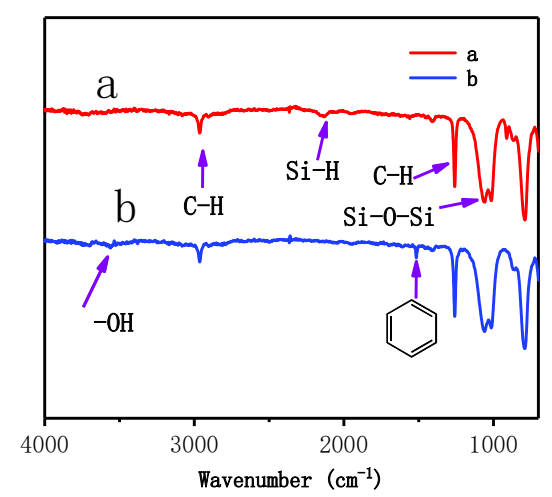

Figure 5. Fourier transform infrared (FT-IR) spectrum of hydrogenterminated siloxane (a) and biophenol terminated siloxane (b).

\subsection{UV Analysis}

After the atoms absorb photons, the outer electrons transition from the ground state to the excited state. Different structures have different ways of transition and different wavelength range of absorbed light. A UV-visible spectrophotometer is commonly used to identify the conjugated olefin and aromatic hydrocarbon in the molecular structure according to wavelength range of absorbed light. Figure 6 shows the UV spectrum of hydrogenterminated siloxane (a) and bio-phenol terminated siloxane (b). As Figure 6 shown, in curve b, a new characteristic absorption tail appeared at the range of 240 to $280 \mathrm{~nm}$ were corresponding to benzene absorption tail, which were derived from eugenol. Combined with the FT-IR spectroscopy analysis above, it was demonstrated that the eugenol was connected to hydrogenterminated siloxane and bio-phenol terminated siloxane was synthesized successfully.

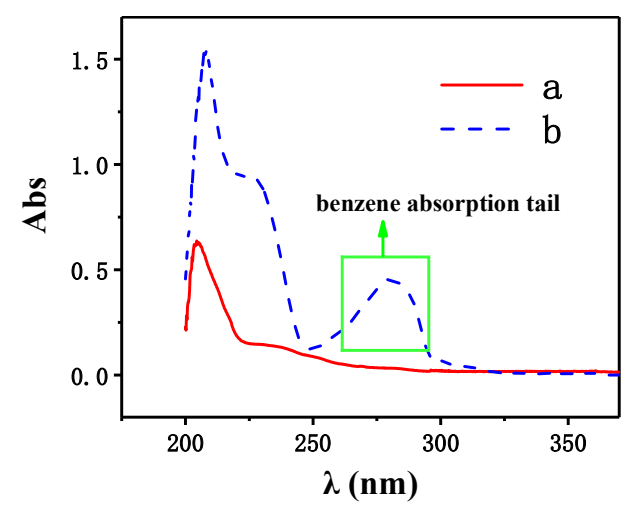

Figure 6. Ultraviolet-visible (UV) spectrum of hydrogenterminated siloxane (a) and bio-phenol terminated siloxane $(\mathbf{b})$.

\subsection{Thermal Analysis}

For providing evidence about effect of eugenol on enhancing the thermal stability of siloxane, the ratio of weight loss was measured. Figure 7 shows the thermogravimetric analysis (TGA) curves of hydrogenterminated siloxane (a) and bio-phenol terminated siloxane (b). In curve a, the first stage of weight loss was volatile water at the range of $80-120^{\circ} \mathrm{C}$ and the second stage was mainly the decomposition of hydrogenterminated siloxane. When the ratio of weight loss reached $98 \%$, the pyrolysis temperature was $603{ }^{\circ} \mathrm{C}$. In curve b, the first stage of weight loss was as same as curve a 
and the second stage was the decomposition of siloxane and residual eugenol. The third stage of weight loss was mainly the decomposition of bio-phenol terminated siloxane. When the ratio of weight loss reached $98 \%$, the pyrolysis temperature was $663{ }^{\circ} \mathrm{C}$ which was $60^{\circ} \mathrm{C}$ higher than hydrogenterminated siloxane. It was demonstrated that the introduction of eugenol had enhanced the thermal stability of siloxane because of the benzene structure in the eugenol.

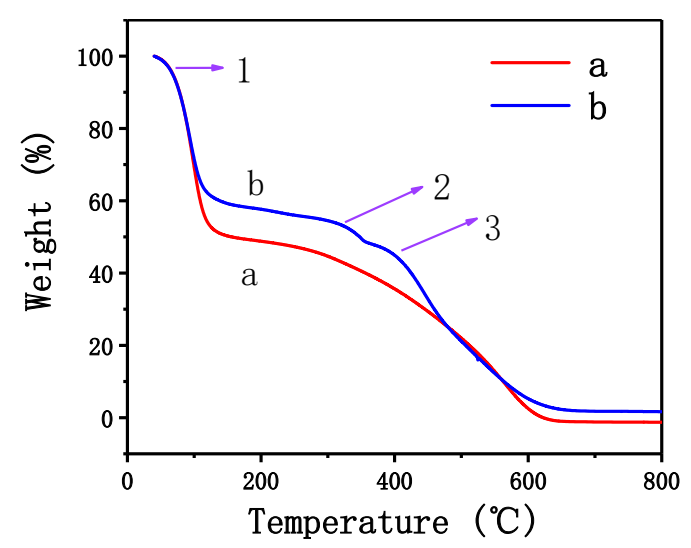

Figure 7. Thermogravimetric analysis (TGA) curves of hydrogenterminated siloxane (a) and bio-phenol terminated siloxane $(\mathbf{b})$.

\subsection{Antimicrobial Activity}

Figure 8 shows optical images of the antimicrobial activities of control group (a), eugenol (b), hydrogenterminated siloxane (c) and bio-phenol terminated siloxane (d). In this assay, agar was used as nutrient solution and the Escherichia coli was used as model to evaluate the antimicrobial activity. In Figure 8a, it was shown that the Escherichia coli bacterial colonies grew quickly within the incubation time of $24 \mathrm{~h}$. In Figure $8 \mathrm{~b}$, the presence of eugenol resulted in almost no visible Escherichia coli bacterial colonies and eugenol had an outstanding antimicrobial activity. Compared with Figure 8c,d, the amount of Escherichia coli bacterial colonies in the agar plate with the presence of bio-phenol terminated siloxane was less than the one with hydrogenterminated siloxane at the same incubation time. It was indicated that the introduction of eugenol had strengthened the antimicrobial activity of siloxane because of the characteristic structure of eugenol. The phenolic hydroxyl group was the main functional group that plays a antimicrobial activity. The ortho-methoxy group could enhance the antibacterial activity. Meanwhile, the antibacterial activity may also be related to the electrical, hydrophobic and spatial structure of bio-phenol siloxane [24]. It was shown that the bio-phenol siloxane had autonomic antimicrobial activity without the addition of antimicrobial agents.

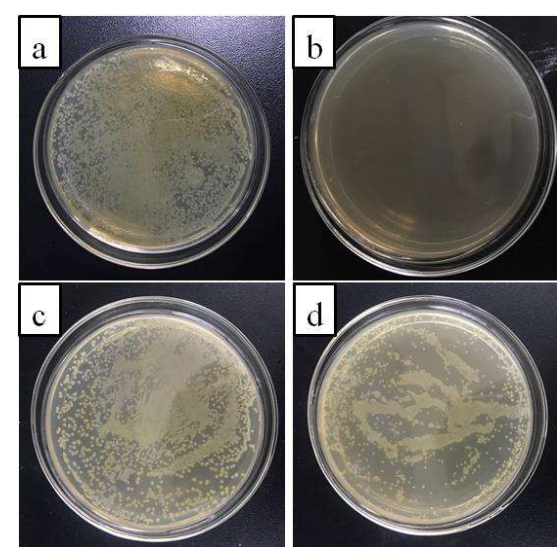

Figure 8. Optical images of agar plates characteristic of the antimicrobial activities of the control group (a), eugenol (b), hydrogenterminated siloxane (c) and bio-phenol siloxane (d). 


\section{Conclusions}

Compared with catalyst $\mathrm{Pt}-\mathrm{Al}_{2} \mathrm{O}_{3}$ and catalyst $\mathrm{Pt}-\mathrm{SiO}_{2}$, we found the catalytic activity of catalyst $\mathrm{Pt}-\mathrm{CNT}$ was preferable, because catalyst Pt-CNT has larger specific surface area and catalytic selectivity in this hydrosilylation reaction between eugenol and hydrogenterminated siloxane. When the catalyst concentration was $100 \mathrm{ppm}$, the reaction temperature was $80^{\circ} \mathrm{C}$ and reaction time was $6 \mathrm{~h}$, the yield reached $97 \%$ and bio-phenol terminated siloxane was synthesized successfully. Meanwhile, when catalyst Pt-CNT was used 4 times after recycling, it also had a high catalytic activity and the yield was still more than $90 \%$. After modification with eugenol, the thermal stability of the obtained bio-phenol terminated siloxane had improved. For bio-phenol siloxane, when the ratio of weight loss reached $98 \%$, the pyrolysis temperature was raised to $663^{\circ} \mathrm{C}$ which was $60{ }^{\circ} \mathrm{C}$ higher than hydrogenterminated siloxane. Its antibacterial property against Escherichia coli was improved significantly. Without the addition of antimicrobial agents, the bio-phenol siloxane had autonomic antimicrobial activity because of special functional groups in the structure. Bio-phenol siloxane is expected to be applied to polymer modification, because it will enhance the thermal stability, weather resistance, hydrophobicity, and antibacterial and antioxidant qualities of the compounds.

Author Contributions: Conceptualization, J.G. and X.C.; Methodology, X.G.; Software, J.J.; Validation, X.P.; Formal Analysis, X.P.; Investigation, X.P.; Resources, J.G.; Data Curation, W.L.; Writing-original Draft Preparation, X.P.; Writing-review and Editing, X.P.; Visualization, J.G.; Supervision, X.G.; Project Administration, J.G.; Funding Acquisition, J.G.

Funding: This work was funded by the Special Funds for Applied Science and Technology Research and Development of Guangdong Province, No. 2015B090925022; and Guangdong Public Welfare Fund and Ability Construction Project, No. 2016A010103037; and Graduate Science and Technology Innovation Fund of Zhongkai University of Agriculture and Engineering, No. KJCX2018007.

Acknowledgments: The authors wish to thank the Zhongkai University of Agriculture and Engineering for financial support.

Conflicts of Interest: The authors declare no conflict of interest.

\section{References}

1. Karapinar, M.; Şahika, E.A. Inhibition of foodborne pathogens by thymol, eugenol, menthol and anethole. Int. J. Food Microbiol. 1987, 4, 161-166. [CrossRef]

2. Shao, Y.; Wu, C.; Wu, T.; Li, Y.; Chen, S.; Yuan, C.; Hu, Y. Eugenol-chitosan nanoemulsions by ultrasound-mediated emulsification: Formulation, characterization and antimicrobial activity. Carbohydr. Polym. 2018, 193, 144. [CrossRef] [PubMed]

3. Pei, R.S.; Feng, Z.; Ji, B.P.; Pei, R.S.; Zhou, F.; Ji, B.P.; Xu, J. Evaluation of combined antibacterial effects of eugenol, cinnamaldehyde, thymol, and carvacrol against E. coli with an improved method. J. Food. Sci. 2010, 74, M379-M383. [CrossRef] [PubMed]

4. Ito, M.; Murakami, K.; Yoshino, M. Antioxidant action of eugenol compounds: Role of metal ion in the inhibition of lipid peroxidation. Food Chem. Toxicol. 2005, 43, 461-466. [CrossRef] [PubMed]

5. Thirukumaran, P.; Parveen, A.S.; Sarojadevi, M. Synthesis of eugenol-based polybenzoxazine-POSS nanocomposites for low dielectric applications. Polym. Compos. 2015, 36, 1973-1982. [CrossRef]

6. Roland, K.; Robert, M.; Michael, F.; Thorsten, S. Use of Eugenol Polyethers and Eugenol Polyethers Siloxanes as Wetting Agents. U.S. Patent 9993766B2, June 2018.

7. Cheng, C.; Li, Y.; Zhang, X.; Li, J. Eugenol-based non-isocyanate polyurethane and polythiourethane. Iran. Polym. J. 2017, 26, 1-11. [CrossRef]

8. Fujisawa, S.; Atsumi, T.; Kadoma, Y.; Sakagami, H. Antioxidant and prooxidant action of eugenol-related compounds and their cytotoxicity. Toxicology 2002, 177, 39-54. [CrossRef]

9. Dai, J.Y.; Yang, S.M.; Teng, N.; Liu, Y.; Liu, X.Q.; Zhu, J.; Zhao, J. Synthesis of Eugenol-Based Silicon-Containing Benzoxazines and Their Applications as Bio-Based Organic Coatings. Coatings 2018, 8, 88. [CrossRef]

10. Miao, J.T.; Yuan, L.; Guan, Q.; Liang, G.; Gu, A. Biobased epoxy resin derived from eugenol with excellent integrated performances and high renewable carbon content. Polym. Int. 2018, 67, 1194-1202. [CrossRef] 
11. Mangeon, C.; Modjinou, T.; Rios de Anda, A.; Thevenieau, F.; Renard, E.; Langlois, V. Renewable semi-interpenetrating polymer networks based on vegetable oils used as plasticized systems of poly(3-hydroxyalkanoate)s. ACS Sustain. Chem. Eng. 2018, 6, 5034-5042. [CrossRef]

12. da Silva, F.F.M.; Monte, F.J.Q.; de Lemos, T.L.G.; do Nascimento, P.G.G.; de Medeiros Costa, A.K.; de Paiva, L.M.M. Eugenol derivatives: Synthesis, characterization, and evaluation of antibacterial and antioxidant activities. Chem. Cent. J. 2018, 12, 34. [CrossRef] [PubMed]

13. Lewis, L.N.; Stein, J.; Gao, Y.; Colborn, R.E.; Hutchins, G. Platinum catalysts used in the silicones industry. Platin. Met. Rev. 1997, 41, 66-75.

14. Januszewski, R.; Kownacki, I.; Maciejewski, H.; Marciniec, B. An efficient catalytic and solvent-free method for the synthesis of mono-organofunctionalized 1,1,3,3-tetramethyldisiloxane derivatives. J. Organomet. Chem. 2017, 846, 263-268. [CrossRef]

15. Xiao, J.J.; Qiu, Z.M.; He, W.J.; Du, C.C.; Zhou, W. Research progress of platinum-catalysts supported by inorganic support-supported hydrosilylation. Chin. J. Org. Chem. 2016, 36, 987-999. [CrossRef]

16. Calvillo, L.; Gangeri, M.; Perathoner, S.; Centi, G.; Moliner, R.; Lázaro, M.J. Effect of the support properties on the preparation and performance of platinum catalysts supported on carbon nanofibers. J. Power. Sources 2009, 192, 144-150. [CrossRef]

17. Cui, X.; Jun, G.K.; Dai, X.; Kreyenschulte, C.; Pohl, M.M.; Wohlrab, S.; Shi, F.; Brückner, A.; Beller, M. Synthesis of single atom based heterogeneous platinum catalysts: High selectivity and activity for hydrosilylation reactions. Acs. Cent. Sci. 2017, 3, 580-585. [CrossRef] [PubMed]

18. Gama-Lara, S.A.; Morales-Luckie, R.; Argueta-Figueroa, L.; Hinestroza, J.P.; García-Orozco, I.; Natividad, R. Synthesis, characterization, and catalytic activity of platinum nanoparticles on bovine-bone powder: A novel support. J. Nanomater. 2018. [CrossRef]

19. Li, W.; Liang, C.; Zhou, W.; Qiu, J.; Zhou, Z.; Sun, G.; Xin, Q. Preparation and characterization of multiwalled carbon nanotube-supported platinum for cathode catalysts of direct methanol fuel cells. J. Phys. Chem. B. 2003, 107, 149-154. [CrossRef]

20. Wu, N.; Li, B.; Liu, J.; Zuo, S.; Zhao, Y. Preparation and catalytic performance of a novel highly dispersed bifunctional catalyst Pt@Fe-MCM-41. RSC Adv. 2016, 6, 13461-13468. [CrossRef]

21. Zgolicz, P.D.; Stassi, J.P.; Yañez, M.J.; Scelza, O.A.; de Miguel, S.R. Influence of the support and the preparation methods on the performance in citral hydrogenation of Pt-based catalysts supported on carbon nanotubes. J. Catal. 2012, 290, 37-54. [CrossRef]

22. Yang, H.; Deng, J.; Liu, Y.; Xie, S.; Wu, Z.; Dai, H. Preparation and catalytic performance of Ag, Au, Pd or Pt nanoparticles supported on $3 \mathrm{DOM} \mathrm{CeO} 2-\mathrm{Al}_{2} \mathrm{O}_{3}$ for toluene oxidation. J. Mol. Catal. A-Chem. 2016, 414, 9-18. [CrossRef]

23. Song, Y.; Jiang, H.; Wang, B.; Kong, Y.; Chen, J. Silver-incorporated mussel-inspired polydopamine coatings on mesoporous silica as an efficient nanocatalyst and antimicrobial agent. ACS Appl. Mater. Interfaces 2018, 10, 1792-1801. [CrossRef] [PubMed]

24. Tang, X.H. Relationship between Antibacterial Activity and Chemical Structure of Cinnamaldehyde, Eugenol and its Structural Analogues. M.S. Thesis, Xiangtan University, 2013.

(C) 2018 by the authors. Licensee MDPI, Basel, Switzerland. This article is an open access article distributed under the terms and conditions of the Creative Commons Attribution (CC BY) license (http:/ / creativecommons.org/licenses/by/4.0/). 